\title{
Bee-plant community in a xeric ecosystem in Argentina
}

\author{
Elen R.F. Michelette ${ }^{1}$ \\ João M.F. Camargo ${ }^{2}$
}

\begin{abstract}
The bee-plant community in a xeric ecosystem in northwestern Argentina was studied concerning diversity, relative abundance, floral preference and phenology. Fifty-seven bee species were recorded, $42.1 \%$ of them endemic to arid regions of southern South America, visiting flowers of 11 plant species. The most abundant bees were Canephorula apiformis (Friese, 1908), Isomalopsis niveata (Friese, 1908) and Melectoides bellus (Jörgensen, 1912). No strictly specialist bee was observed. Some aspects of bee-flowers associations and distribution patterns are discussed.

KEY WORDS. Bee-plant interaction, Monte Province, arid ecosystem, biogeography
\end{abstract}

The arid and semiarid habitats, especially in the subtropics, support complex and peculiar communities of bees-plants. In South America, the arid and semiarid regions are located chiefly in southwestern parts of the continent, predominantly in Argentina and Chile, as well as in Bolivia and Peru, but there are also arid regions in Venezuela-Colombia and northeastern Brazil. In Argentina, the deserts and subdeserts constitute a long pre-Andean belt, the "Cordilleranos", ranging from north to south of the country. This area is believed to comprise "refuges" for groups associated with arid conditions (STANGE et al. 1976).

Some aspects of the apifauna of xeric places of Argentina and adjacent areas were studied by JöRGENSEN (1912), STANGE et al. (1976), MOLDENKE (1976b, 1979b) and MiCHENER (1979). Nevertheless, no systematic survey of the bee-plant community was carried out.

The objective of this work was to help fill this gap, by means of a standardized survey of the bee fauna, of an area in western Argentina, regarding composition, relative abundance, phenology and associations with flowers. Brief considerations about the distribution patterns of the bee fauna and associated flora are also presented.

\section{MATERIAL AND METHODS}

\section{Study Site}

The study site (1.0 ha) is situated in the Valley of Zonda - Ullum $\left(68^{\circ} 40^{\prime} \mathrm{W}\right.$, $31^{\circ} 33$ 'S), in the Monte Biogeographic Province (CABRERA \& WiLLINK 1973), close to the western slope of the "Sierra Chica de Zonda" (Fig. 1), in San Juan, Argentina. The valley constitutes a tectonic depression (altitude $900 \mathrm{~m}$ ), characterized by the

1) Universidade Tiradentes. Avenida Dr. José Thomas D'Avila Nabuco, 300, 49030-270 Aracaju, Sergipe, Brasil.

2) Departamento de Biologia, Faculdade de Filosofia, Ciências e Letras de Ribeirão Preto, Universidade de São Paulo. Avenida dos Bandeirantes 3900, 14040-901 Ribeirão Preto, São Paulo, Brasil. 
accumulation of quaternary lacustre sediments (APARICIO 1966, 1984). In the dry areas of the Zonda Valley, predominate the "matorrales", a shrubby xerophytic vegetation (Fig. 2) characterized by species of Larrea, Bulnesia (Zygophyllaceae) and Prosopis (Leguminosae). At more humid places, at the banks of a seasonally dry river ("Zonda swamp"), species such as Tessaria absinthioides, Baccharis salicifolia (Compositae), Tamarix gallica (Tamaricaceae) and Proposis strombulifera (Leguminosae) are found.

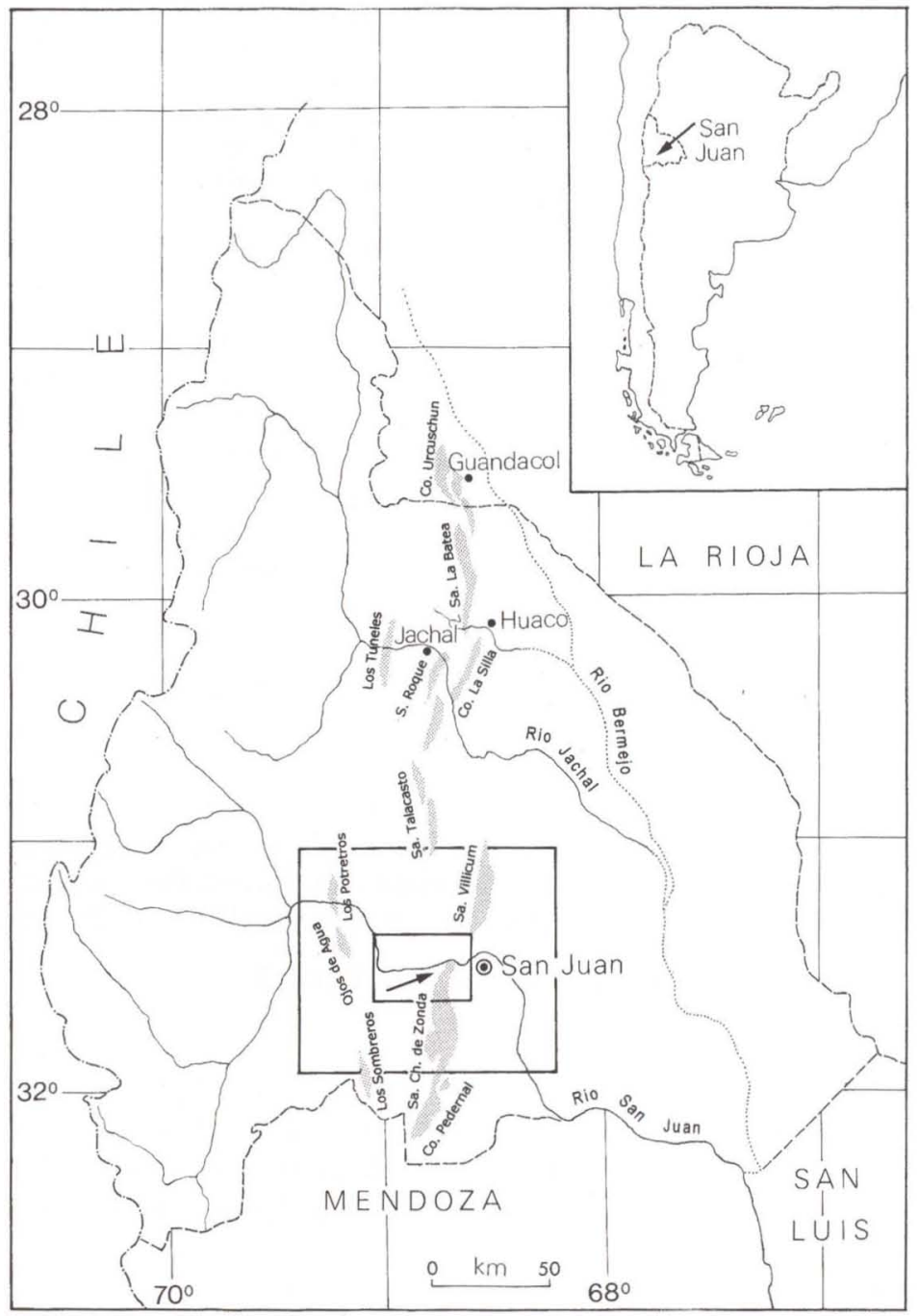

Fig. 1. Location of the Valley of Zonda - Ullum (indicated by arrow), San Juan, Argentina. 

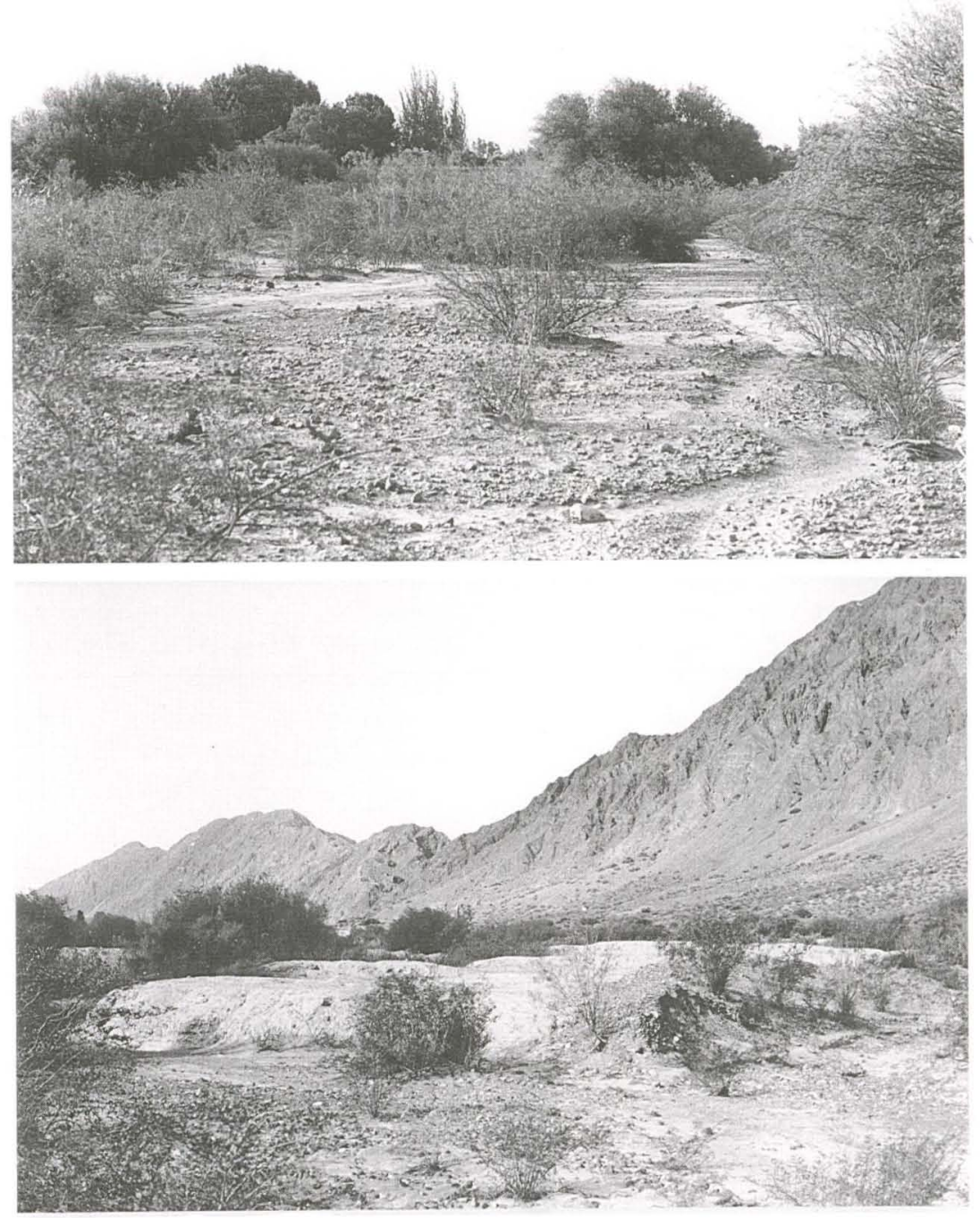

Fig. 2. Landscapes of the Valley of Zonda - Ullum, San Juan, Argentina.

The Zonda Valley has a desert climate (BWk, Köppen classification). Rains occur primarily from January through March, with an annual average precipitation of $96.3 \mathrm{~mm}$. During the sampling period (May/1993 to April/1994) the precipitation was $76.9 \mathrm{~mm}$, with a peak of $48.0 \mathrm{~mm}$ in February. The mean temperature was $15^{\circ} \mathrm{C}$. January was the warmest month, with an average of $26^{\circ} \mathrm{C}$, and July the coldest, with $6.5^{\circ} \mathrm{C}$; the maximum temperature $\left(41^{\circ} \mathrm{C}\right)$ was recorded in December and the minimum $\left(0.6^{\circ} \mathrm{C}\right)$ in July (Fig. 3$)$. 


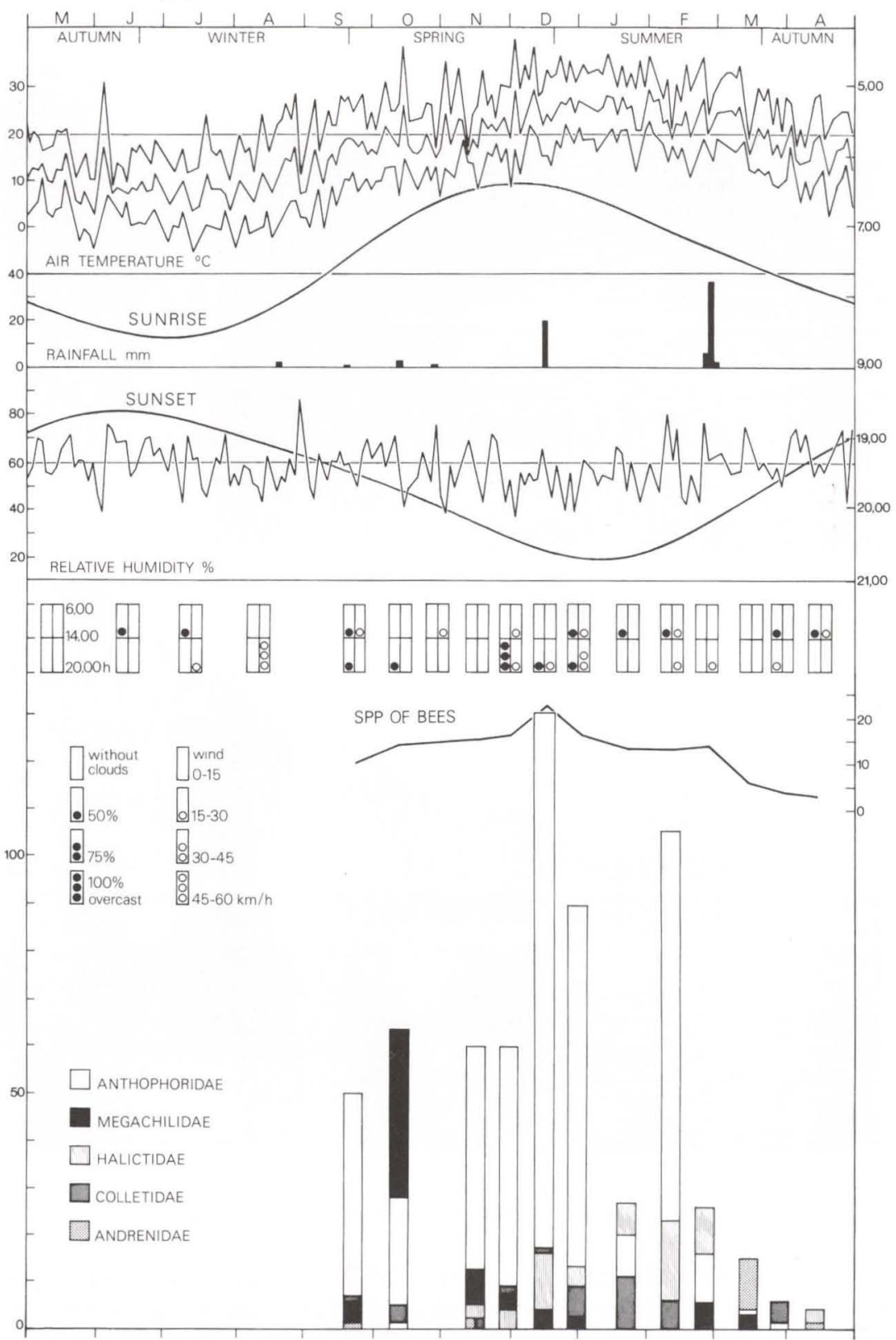

Fig. 3. Relative abundance of bees in Zonda Valley, San Juan, Argentina, and daily climatic data, from May 1993 to April 1994. The columns indicates the total of individuals per family collected in each sampling. 


\section{Bee and plant sampling}

The samples were taken every 15 days from May 1993 to April 1994. According to the season, the sampling period lasted from 10 to 15 hours (for the longest days of the year, divided into two periods, from 6:00 to 14:00 $\mathrm{h}$ on the first day, and from 14:00 to 21:00 on the second). The bees were collected with nets on flowers in a systematic sampling scheme. The whole area was covered by one collector at one-hour intervals, staying 3 to 5 minutes at each plant regardless of the bee frequency there.

Bees and voucher specimens of the plants are deposited in the Departamento de Biologia, Faculdade de Filosofia, Ciências e Letras de Ribeirão Preto - USP, São Paulo, Brasil (RPSP).

\section{RESULTS}

\section{Apifauna: diversity, phenology, frequency and floral associations}

During the survey, 924 bees of 57 species ( 30 genera, 6 families) were collected (Tab. I). The family best represented in number of species as well as individuals, was Anthophoridae, followed by Halictidae, Megachilidae, Colletidae, Andrenidae and Apidae (Tab. I). Most of the species sampled (45.6\%) were represented by two to eight individuals, and $22.8 \%$ by only one. The most abundant species were Canephorula apiformis (211 individuals), Isomalopsis niveata (133) and Melectoides bellus (102) (Tab. I).

Bees were active from September to April (Figs 3, 4). Anthophoridae and Colletidae were recorded from September to March, Halictidae from November to April, and Andrenidae in September, November, March and April. Megachilidae exhibited two periods of activity, the first from September to December, and the second, with a much smaller number of individuals, between February and March. The largest number of species and individuals were recorded in December, when there was a predominance of Anthophoridae. This family was the most abundant in other months also, except in October when Megachilidae predominated and in January and March when Colletidae and Andrenidae, respectively, were the best represented families (Figs 3, 4).

Bees visited mainly flowers of Compositae plants ( 309 bee specimens of the total sampled), Zygophyllaceae (280), Capparaceae (221) and Leguminosae (108) (Tab. II).

The frequencies of bees on flowers of different plant species are summarized in table I. Andrenidae visited exclusively the flowers of Zygophyllaceae: Larrea divaricata $(27.3 \%)$ and Bulnesia retama $(72.7 \%)$. Megachilidae visited preferentially L. divaricata (84.2\%), Halictidae, Baccharis salicifolia (39.5\%) and L. divaricata $(24.4 \%)$ and Anthophoridae, Atamisquea emarginata (31.0\%) and Tessaria absinthioides (30.4\%). Colletidae visited preferentially B. salicifolia $(32.4 \%)$ and Prosopis strombulifera (25.7\%). Most of bee species visited exclusively or preferentially flowers of Zygophyllaceae, mainly L. divaricata and B. retama (Tab. I), such as Lonchopria robertsi (Michener, 1989), Colletes longiceps Friese, 1910 ( $100 \%$ of the individuals), all species of Andrenidae (100\%), most of Megachilidae [Megachile spp. (93\%), Anthidium spp. (100\%)], Centris muralis Burmeister, 1876 (97.3\%), and all species of Xylocopa Latreille, 1802 (95.5\%). 
Table I. Number of bees collected on flowers in the arid valley of Zonda, San Juan, Argentina, from May 1993 to April 1994. (A) Prosopis strombulifera, (B) Cassia aphylla, (C) Tessaria absinthioides, (D) Baccharis salicifolia (E) Larrea divaricata, (F) Larrea cuneifolia, (G) Bulnesia retama, (H) Atamisquea emarginata, (I) Solanum sisymbrifolium, (J) Atriplex sp., (K) Phoradendron sp., (*) Species; (**) genus endemic to desert areas of western and central Argentina; $(+)$ genus; $(++)$ subgenus with amphitropical distribution: southern South America and southwestern United States and northwestern Mexico.

\begin{tabular}{|c|c|c|c|c|c|c|c|c|c|c|c|c|c|c|c|}
\hline \multirow{2}{*}{ Bee taxa } & \multirow{2}{*}{ Distribution - } & \multicolumn{11}{|c|}{ Plant taxa } & \multirow{2}{*}{ Females } & \multirow{2}{*}{ Males } & \multirow{2}{*}{$\mathrm{n}$} \\
\hline & & A & B & c & $\mathrm{D}$ & $E$ & $\mathrm{~F}$ & G & $\mathrm{H}$ & 1 & $\mathrm{~J}$ & $\mathrm{~K}$ & & & \\
\hline \multicolumn{16}{|l|}{ Colletidae (Diphaglossinae) } \\
\hline Caupolicana mystica (Schrottky, 1902) & ${ }^{*}+$ & - & - & - & - & - & - & - & 6 & - & - & - & 2 & 4 & 6 \\
\hline Willinkapis chalybaea (Friese, 1906) & * & - & - & - & - & - & - & - & 1 & - & - & - & - & 1 & 1 \\
\hline \multicolumn{16}{|l|}{ Colletidae (Colletinae) } \\
\hline Leioproctus (Nomiocolletes) jenseni (Friese, 1906) & * & 19 & - & 5 & 6 & - & - & - & - & - & 1 & - & 27 & 4 & 31 \\
\hline Leioproctus (Nomiocolletes) joergenseni (Friese, 1908) & * & - & - & - & 7 & - & - & - & - & - & - & - & 2 & 5 & 7 \\
\hline Leioproctus (Bicolletes) neotropicus (Friese, 1908) & * & - & - & - & 11 & - & - & - & - & - & - & - & 5 & 6 & 11 \\
\hline Leioproctus (Bicolletes) sp. & * & - & - & - & - & - & - & 2 & - & - & - & - & - & 2 & 2 \\
\hline Lonchopria (Biglossa) chalybaea (Friese, 1906) & * & - & - & - & - & - & - & - & 5 & - & - & - & 4 & 1 & 5 \\
\hline Lonchopria (Biglossa) robertsi (Michener, 1989) & * & - & - & - & - & 1 & - & 4 & - & - & - & - & 2 & 3 & 5 \\
\hline Colletes cf. longiceps Friese, 1910 & * & - & - & - & - & 3 & - & 2 & - & - & - & - & 3 & 2 & 5 \\
\hline \multicolumn{16}{|l|}{ Colletidae (Xeromelissinae) } \\
\hline Chilicola sp. & & - & - & - & - & 1 & - & - & - & - & - & - & 1 & - & 1 \\
\hline Total of Colletid bees & & 19 & - & 5 & 24 & 5 & - & 8 & 12 & - & 1 & - & 46 & 28 & 74 \\
\hline
\end{tabular}

\section{Andrenidae (Panurginae)}

Parasarus sp.

Callonychium (Paranychium) minutum Friese, 1906

Calliopsis (Liopoeum) argentina (Jörgensen, 1912)

Total of Andrenid bees

\begin{tabular}{|c|c|c|c|c|c|c|c|c|c|c|c|c|c|}
\hline * & - & - & - & 1 & - & 15 & - & - & - & - & 6 & 10 & 16 \\
\hline * & - & - & - & 2 & - & - & - & - & - & - & - & 2 & 2 \\
\hline+ & - & - & - & 3 & - & 1 & - & - & - & - & 2 & 2 & 4 \\
\hline & - & - & - & 6 & - & 16 & - & - & - & - & 8 & 14 & 22 \\
\hline
\end{tabular}

\section{Halictidae (Halictinae)}

Augochloropsis argentina (Friese, 1908)

Augochloropsis sp. 1

Augochloropsis sp. 2

Dialictus (Chloralictus) autranellus Vachal, 1904

Dialictus (Chloralictus) phaedrus (Schrottky, 1910)

$\begin{array}{cccc}1 & - & - & 10 \\ - & - & - & 2 \\ - & - & - & - \\ - & - & - & 1 \\ 6 & - & 6 & 19\end{array}$

$\begin{array}{llll}1 & - & - & - \\ - & - & - & - \\ 1 & - & - & - \\ - & - & - & 4 \\ 11 & - & - & 2\end{array}$


Table I. Continued. (A) Prosopis strombulifera, (B) Cassia aphylla, (C) Tessaria absinthioides, (D) Baccharis salicifolia (E) Larrea divaricata, (F) Larrea cuneifolia, (G) Bulnesia retama, (H) Atamisquea emarginata, (I) Solanum sisymbrifolium, (J) Atriplex sp., (K) Phoradendron sp., (*) Species: $\left(^{* *}\right)$ genus endemic to desert areas of western and central Argentina; $(+)$ genus; $(++)$ subgenus with amphitropical distribution: southern South America and southwestern United States and northwestern Mexico.

\begin{tabular}{|c|c|c|c|c|c|c|c|c|c|c|c|c|c|c|c|}
\hline \multirow{2}{*}{ Bee taxa } & \multirow{2}{*}{ Distribution - } & \multicolumn{11}{|c|}{ Plant taxa } & \multirow{2}{*}{ Females } & \multirow{2}{*}{ Males } & \multirow{2}{*}{$n$} \\
\hline & & A & B & $\mathrm{C}$ & D & $E$ & $\mathrm{~F}$ & G & $\mathrm{H}$ & 1 & $\mathrm{~J}$ & $\mathrm{~K}$ & & & \\
\hline Dialictus (Chloralictus) opacus (Moure, 1940) & & 2 & - & 1 & 11 & 5 & 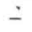 & - & 7 & - & - & 3 & 24 & 5 & 29 \\
\hline Dialictus (Chloralictus) aff. opacus (Moure, 1940) & & - & - & - & - & 8 & - & - & 4 & - & - & - & 12 & - & 12 \\
\hline Dialictus (Chloralictus) hualitchu (Holmberg, 1886) & & 1 & - & 1 & - & 1 & - & - & - & - & - & - & 3 & - & 3 \\
\hline Dialictus (Chloralictus) cf. phleboleucus (Moure, 1956) & & - & - & - & 1 & - & - & - & - & - & - & - & - & 1 & 1 \\
\hline Dialictus (Chloralictus) cf. rhythidophorus (Moure, 1956) & & - & - & 2 & - & - & - & - & - & - & - & - & 2 & - & 2 \\
\hline Dialictus (Chloralictus) sp. 1 & & - & - & - & 1 & 2 & - & - & 1 & - & - & 1 & 3 & 2 & 5 \\
\hline Caenohalictus thauca (Schrottky, 1913) & * & - & - & - & 1 & - & - & - & 1 & - & - & - & 1 & 1 & 2 \\
\hline Sphecodes (Austrosphecodes) sp. 1 & & - & - & - & 1 & - & - & - & - & - & - & - & - & 1 & 1 \\
\hline Total of Halictid bees & & 10 & - & 10 & 47 & 29 & - & - & 19 & - & - & 4 & 104 & 15 & 119 \\
\hline
\end{tabular}

\section{Megachilidae (Megachilinae)}

Megachile (Chrysosarus) cf. obdurata Mitchell, 1930

D. Megachile (Chrysosarus) pseudanthidioides Moure, 1943

Megachile (Chrysosarus) sp. 1

Megachile (Chrysosarus) sp. 2

Megachile (Chrysosarus) sp. 3

Megachile (Chrysosarus) sp. 4

Megachile (Chrysosarus) sp. 5

Megachile (Leptorachis) sp.

Epanthidium of. bicoloratum (Smith, 1879)

Anthidium sp. 1

Anthidium sp 2

Total of Megachilid bees

$\begin{array}{lll}- & - & - \\ - & - & - \\ - & 1 & - \\ - & - & - \\ - & - & - \\ - & - & - \\ - & 1 & - \\ - & - & - \\ 1 & - & - \\ - & - & - \\ - & - & - \\ 1 & 2 & -\end{array}$

\section{Anthophoridae (Anthophorinae)}

Canephorula apiformis (Friese, 1920)

Svastra (Svastra) bombilans Holmberg, 1884

Svastrides zebra (Friese, 1908)

$\begin{array}{ccccccccccc}- & - & - & - & 2 & - & - & - & - & 2 & 2 \\ - & - & - & - & 1 & - & - & - & 1 & - & 1 \\ - & 46 & 1 & 3 & - & - & - & - & 45 & 6 & 51 \\ - & 3 & - & - & - & - & - & - & 3 & - & 3 \\ - & 1 & - & - & - & - & - & - & 1 & - & 1 \\ - & 2 & - & 2 & - & - & - & - & 4 & - & 4 \\ - & 6 & - & 2 & - & - & - & - & 9 & - & 9 \\ - & 1 & - & - & - & - & - & - & 1 & - & 1 \\ - & 1 & - & - & 1 & - & - & - & 1 & 2 & 3 \\ - & 29 & - & 2 & - & - & - & - & 14 & 17 & 31 \\ - & 2 & - & - & - & - & - & - & 2 & - & 2 \\ - & 91 & \mathbf{1} & 9 & 4 & - & - & - & \mathbf{8 1} & 27 & 108\end{array}$

$\begin{array}{cccccccccccccc}3 & - & 110 & 36 & 22 & - & - & 40 & - & - & - & 43 & 168 & 211 \\ 3 & - & 1 & - & - & - & - & 27 & - & - & - & 1 & 30 & 31 \\ - & - & - & - & 1 & - & - & - & - & - & - & 1 & - & 1 \\ \text { Continue }\end{array}$


Table I. Continued. (A) Prosopis strombulifera, (B) Cassia aphylla, (C) Tessaria absinthioides, (D) Baccharis salicifolia (E) Larrea divaricata, (F) Larrea cuneifolia, (G) Bulnesia retama, (H) Atamisquea emarginata, (I) Solanum sisymbrifolium, (J) Atriplex sp., (K) Phoradendron sp., ( $\left.{ }^{*}\right)$ Species: $\left(^{* \star}\right)$ genus endemic to desert areas of western and central Argentina; $(+)$ genus; $(++)$ subgenus with amphitropical distribution: southern South America and southwestern United States and northwestern Mexico.

\begin{tabular}{|c|c|c|c|c|c|c|c|c|c|c|c|c|c|c|c|}
\hline \multirow{2}{*}{ Bee taxa } & \multirow{2}{*}{ Distribution - } & \multicolumn{11}{|c|}{ Plant taxa } & \multirow{2}{*}{ Females } & \multirow{2}{*}{ Males } & \multirow{2}{*}{$\mathrm{n}$} \\
\hline & & A & B & $\mathrm{C}$ & $\mathrm{D}$ & $E$ & $\mathrm{~F}$ & G & $\mathrm{H}$ & 1 & $\mathrm{~J}$ & $\mathrm{~K}$ & & & \\
\hline Melissoptila (Ptilomelissa) dama (Vachal, 1904) & & - & - & - & 3 & - & - & - & - & - & - & - & 3 & - & 3 \\
\hline Isomalopsis niveata (Friese, 1908) & $*$ & 13 & 4 & - & 1 & 4 & - & - & 111 & - & - & - & 39 & 94 & 133 \\
\hline Eremapis parvula (Ogloblin, 1956) & $*$ & 9 & 1 & - & - & 2 & - & - & 2 & - & - & - & 13 & 1 & 14 \\
\hline Exomalopsis (Exomalopsis) sp. & & - & - & - & - & - & - & - & 1 & - & - & - & - & 1 & 1 \\
\hline Mesonychium sp. & & - & - & 1 & - & - & - & - & - & - & - & - & - & 1 & 1 \\
\hline Centris (Paracentris) lyngbyei Jensen-Haarup, 1908 & $*(+)$ & 1 & 1 & - & - & - & - & - & - & - & - & - & 2 & - & 2 \\
\hline Centris (Paracentris) brethesi Schrottky, 1902 & ${ }^{*}(+)$ & - & - & - & - & 3 & - & 1 & 4 & - & - & - & 1 & 7 & 8 \\
\hline Centris (Hemisiella) sp. & & - & - & - & - & 1 & - & - & - & - & - & - & 1 & - & 1 \\
\hline Centris (Wagenknechtia) muralis Burmeister, 1876 & * & - & - & - & - & 18 & 1 & 18 & - & - & - & - & 20 & 17 & 37 \\
\hline \multicolumn{16}{|l|}{ Anthophoridae (Xylocopinae) } \\
\hline Xylocopa (Neoxylocopa) mendozana Enderlein, 1913 & * & - & 1 & - & - & 4 & - & 5 & - & 1 & - & - & 9 & 2 & 11 \\
\hline Xylocopa (Neoxylocopa) sp. & & - & - & - & - & - & - & 3 & - & - & - & - & 3 & - & 3 \\
\hline Xylocopa (Nanoxylocopa) ciliata Burmeister, 1876 & & - & - & - & - & 3 & - & - & - & - & - & - & 3 & - & 3 \\
\hline Xylocopa (Schoenherria) splendidula Lepeletier, 1841 & & - & - & - & - & 5 & - & 23 & - & - & - & - & 2 & 26 & 28 \\
\hline Ceratina volitans (Schrottky, 1907) & & - & - & 8 & - & - & - & - & - & - & - & - & 6 & 2 & 8 \\
\hline \multicolumn{16}{|l|}{ Anthophoridae (Nomadinae) } \\
\hline Melectoides bellus (Jörgensen, 1912) & • & 39 & - & 62 & - & - & - & - & 1 & - & - & - & 10 & 92 & 102 \\
\hline Doeringiella bipunctata (Friese, 1908) & * & 1 & - & - & - & - & - & - & - & - & - & - & - & 1 & 1 \\
\hline Total of Anthophorid bees & & 69 & 7 & 182 & 40 & 63 & 1 & 50 & 186 & 1 & - & - & 157 & 442 & 599 \\
\hline
\end{tabular}

Apidae (Apinae)

Bombus opifex Smith, 1859

Total of Apid bees

Total bee sample

$-$

99

$9 \quad 198$




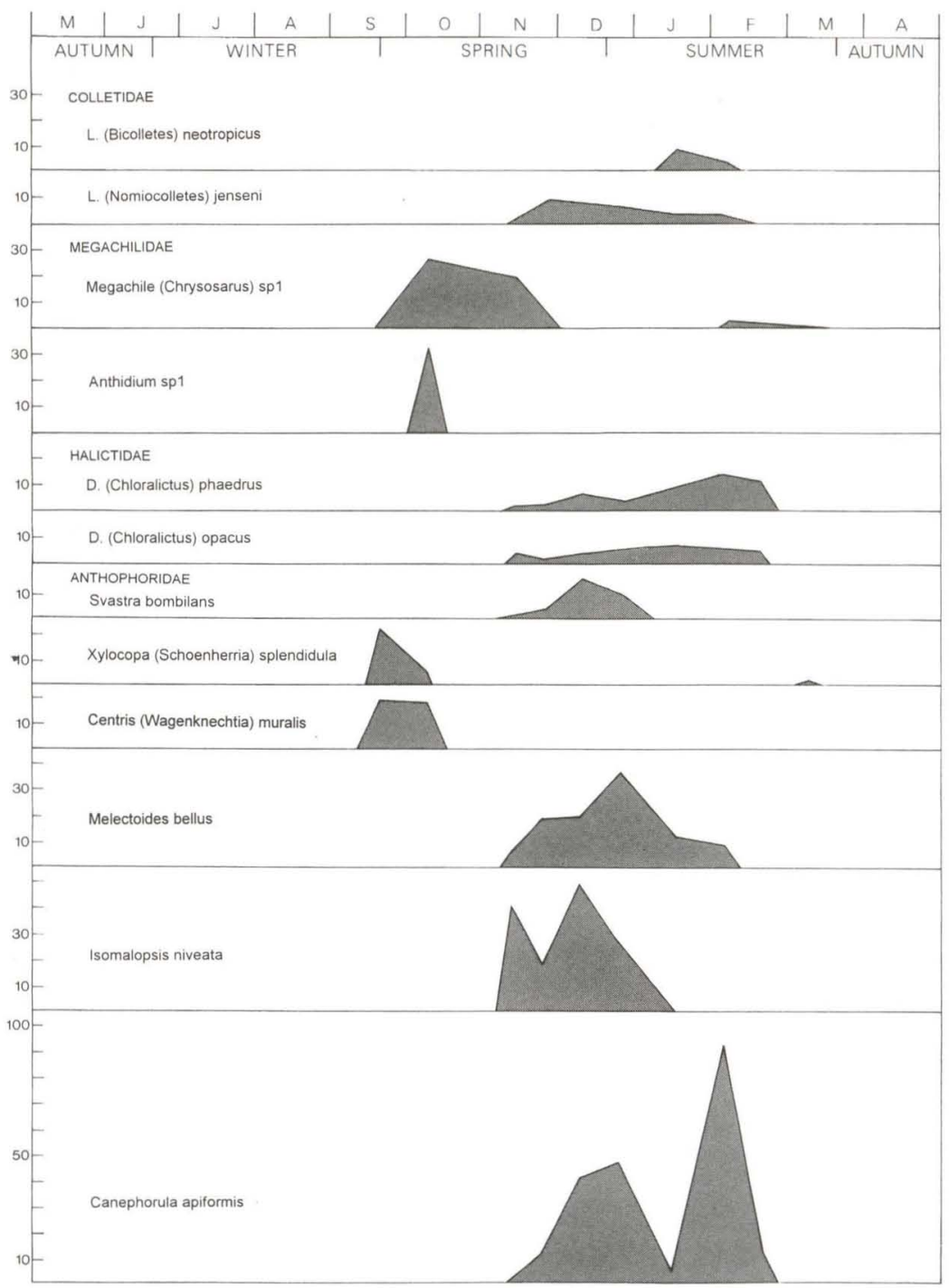

Fig. 4. Phenology of the most abundant bee species in Zonda Valley, San Juan, Argentina, from May 1993 to April 1994. The $y$-axis indicates the total number of individuals collected per sampling.

The Andrenidae and the most abundant species of Megachilidae were active mainly in the blooming periods of Zygophyllaceae flowering (Figs 3-4, Tabs I-II). The Panurginae, Parasarus Ruz, in Ruz and Rozen, 1993 (one unidentified species) and Callonychium minutum Friese, 1906, were active in late summer and Calliopsis argentina (Jörgensen, 1912) in the spring, all visiting L. divaricata and B. retama. 
Table II. Number of bees sampled monthly per plant species, in the arid valley of Zonda, San Juan, Argentina, from May 1993 to April 1994. Black lines indicate flowering periods.

\begin{tabular}{|c|c|c|c|c|c|c|c|c|c|}
\hline \multirow{2}{*}{ Plant taxa } & \multicolumn{4}{|c|}{1993} & \multicolumn{4}{|c|}{1994} & \multirow{2}{*}{$\mathrm{n}$ bees } \\
\hline & September & October & November & December & January & February & March & April & \\
\hline \multicolumn{10}{|l|}{ Zygophyllaceae } \\
\hline Bulnesia retama (1) & 59 & 4 & & & & 0 & 20 & & 83 \\
\hline Larrea cuneifolia (2) & 1 & 1 & & & & & & & 2 \\
\hline Larrea divaricata (3) & 3 & 91 & 45 & 1 & & 49 & 5 & 1 & 195 \\
\hline \multicolumn{10}{|l|}{ Leguminosae } \\
\hline Cassia aphylla (4) & 0 & 4 & 5 & & & & & & 9 \\
\hline Prosopis strombulifera (5) & & & 70 & 29 & & & & & 99 \\
\hline \multicolumn{10}{|l|}{ Capparaceae } \\
\hline Atamisquea emarginata (6) & & & 45 & 175 & 0 & 1 & & & 221 \\
\hline \multicolumn{10}{|l|}{ Solanaceae } \\
\hline Solanum sisymbrifolium & & & 1 & & & & 0 & 0 & .1 \\
\hline \multicolumn{10}{|l|}{ Compositae } \\
\hline Baccharis salicifolia (7) & & & & 5 & 38 & 61 & 7 & & 111 \\
\hline Tessaria absinthioides (8) & & & & 104 & 19 & 75 & & & 198 \\
\hline \multicolumn{10}{|l|}{ Chenopodiaceae } \\
\hline Atriplex sp. (9) & & & & & & 1 & & & 1 \\
\hline \multicolumn{10}{|l|}{ Loranthaceae } \\
\hline Phoradendron sp. & & & & & & & & 4 & 4 \\
\hline Total bee sample & 63 & 100 & 166 & 314 & 57 & 187 & 32 & 5 & 924 \\
\hline \multicolumn{10}{|c|}{$\begin{array}{l}\text { *) Geographic distribution of plants according to KIESLING (1994): 1) Argentina to Peru; 2) } \\
\text { Deserts and semideserts in Chile, Peru and Bolivia, in Argentina from Salta to Chubut; 3) } \\
\text { Deserts and semideserts in Argentina, Chile, Peru and Bolivia; 4) Argentina, one of the most } \\
\text { abundant elements in the "Monte" vegetation; 5) Chile, Peru, western Argentina, from Salta to } \\
\text { Neuquen, Buenos Aires; 6) Bolivia, Chile and Argentina (all provinces north of Rio Negro), } \\
\text { northern Mexico and southwestern USA; 7) South America; 8) Bolivia, Chile, Uruguay and } \\
\text { Argentina; 9) The genus is widely distributed, inhabiting arid and saline soils. }\end{array}$} \\
\hline
\end{tabular}

Two Paracolletini, Leioproctus (Nomiocolletes) joergenseni (Friese, 1908) and $L$. (Bicolletes) neotropicus (Friese, 1908), visited exclusively the flowers of $B$. salicifolia (Tab. I). Among the Anthophoridae, Isomalopsis niveata and Svastra bombilans, were more abundant on flowers of $A$. emarginata $(83.5 \%$ and $87.1 \%$ respectively). The other taxa were more generalist, such as the Halictidae and most of the Anthophoridae species. Canephorula apiformis was more abundant on flowers of $T$. absinthioides, A. emarginata, B. salicifolia and L. divaricata, and Melectoides bellus on flowers of T. absinthioides and P. strombulifera. 


\section{Flora: diversity and flowering phenology}

Plants of 23 species belonging to 11 families were sampled in the study site, but only 11 species were visited by bees (Tabs I, II). The most diverse families were Leguminosae (7 spp.), Compositae (4 spp.) and Zygophyllaceae (3 spp.).

The flowering was restricted to Spring-Summer (September to April). Some species presented two blooming periods; the most important, by their predominance in the ecosystem, were Larrea divaricata and Bulnesia retama (Tab. II). In September and October, only Zygophyllaceae species were flowering, except for some individuals of Cassia aphylla (Leguminosae). In November, flowering plants of Leguminosae were dominant, in December, Capparaceae (with a single species, Atamisquea emarginata) and Compositae, and from January to February flowering Compositae were most abundant (Tab. II).

Besides the plants visited by bees, listed in table II, the following species were also recorded in the area: Prosopis chilensis, P. flexuosa, Acacia aroma, Cercidium praecox, Mimosa ephedroides (Leguminosae), Hyalis argentea, Tagetes sp. (Compositae), Tamarix gallica (Tamaricaceae), Bougainvillea spinosa (Nyctaginaceae), Verbena mendocina (Verbenaceae), Phoradendron liga (Loranthaceae) and Brassica sp. (Cruciferae).

\section{DISCUSSION}

\section{Bee diversity and distribution}

The bee fauna recorded in a restricted area of Zonda Valley is not directly comparable, in terms of diversity (only 57 species), with that of other arid and semiarid regions, where extensive studies have been made. Sampling in some of these regions covered much larger geographic areas and longer periods. In the desert areas of California, 688 species have been recorded (MOLDENKE 1976 a,b), 229 in central-western Argentina (JÖRGENSEN 1912) and 176 in the desert areas of Chile (MOLDENKE 1979b).

Despite the small number of species recorded in Zonda Valley, the data reveal a hybrid community, including elements with distinct biogeographical histories, such as taxa (tribes and genera) of austral distribution, autochthonous or with gondwanic affinities, Neotropical, amphitropical and widespread taxa, like Colletes Latreille, 1802, that occurs in all continents, except in the Orient and Australia (cf. MICHENER 1979).

The Paracolletini (Colletidae), one of the most conservative groups of bees, has a disjunct distribution in the austral terranes (Australian region and southern part of South America, principally), which could indicate the presence of a common ancestral biota, before the fragmentation of the southern terranes of the Gondwana continent (MICHENER 1979: 302, 1989). In the study area this tribe was represented by six species, belonging to two genera, Leioproctus Smith, 1853 and Lonchopria Vachal, 1905. Some of these taxa present, possibly, a disjunct distribution in South America: Leioproctus (Nomiocolletes) Brèthes, 1909, is found mainly in central Argentina and in Bolivia, with one species of this subgenus recorded from the Diamantina region, Minas Grais, Brazil (Dr. J.S. Moure, pers. comm.), and another 
one, L. (Nomiocolletes) cearensis (Ducke, 1908) in the Brazilian northeast (DUCKE 1910). On the other hand, Lonchopria (Biglossa) Friese, 1906 is distributed through western South America, from Argentina (Mendoza) to Colombia, in the Andean and subandean eastern regions (MICHENER 1989).

Another interesting group of the Colletidae, is the genus Caupolicana Spinola, 1851 (Caupolicanini), with amphitropical distribution (MICHENER 1979). In South America it occurs in Argentina, Chile, southern Brazil, and recently one species was found in central-eastern Brazil, in Serra do Cipó - Minas Gerais (Faria, inf. pessoal), and it also appears in the desert areas of North America (MICHENER 1979).

The Panurginae (Andrenidae) are very diversified in the Western Hemisphere, with the majority of the species occurring in arid or subarid regions. Among the bees of this subfamily collected in the present work, the genus Calliopsis Smith, 1853, also shows amphitropical distribution (MICHENER 1979), though more extended when compared to Caupolicana. The Panurginae present on both continents (North and South America) exhibit great differentiation, with few genera in common, which indicates that disjunction could have occurred, in very ancient times, before the continental connection through the Panama isthmus (MICHENER 1979).

Some genera of Anthophoridae recorded in the Zonda Valley, like Xylocopa and Ceratina Latreille, 1802, are widely distributed, but there are groups with more restricted distributions (Tab. I), such as Centris (Wagenknechtia) Moure, 1950, Svastra (Svastra) Holmberg, 1884, Svastrides Michener, LaBerge $\&$ Moure, 1955 and the parasitic genus Melectoides Taschenberg, 1883, which are found in Argentina and Chile (Moure 1950; Roig-Alsina 1991) and the monotypic genera Canephorula Jörgensen, 1909, Isomalopsis Michener \& Moure, 1957 and Eremapis Ogloblin, 1956, endemic to Argentina (MichENER et al. 1955; Michener \& Moure 1957; Silveira 1995). The subgenus Paracentris Cameron, 1903, exhibits amphitropical distribution, though it has a more extensive range, considering that it extends as far as the Ecuadorian Andes. About eight species of this subgenus were registered in desert areas of the southwestern United States (Hurd \& Linsley 1975; SNelling 1974, 1984). The species of Paracentris collected in Zonda Valley, C. (Paracentris) lyngbyei Jensen-Haarup, 1908 (= C. tricolor Friese, 1900, partim) and C. (Paracentris) brethesi Schrottky, 1902, occur mainly in central and western Argentina (JÖRGENSEN 1912), but one other species of this group, C. (Paracentris) klugi Friese, 1900, was registered in xeric regions of central-eastern Brazil, associated with areas above $1400 \mathrm{~m}$ (SILVEIRA \& CURE 1993). This pattern of disjunction between the central-eastern Brazil and Argentinian xeric areas, as in the case of Paracentris, could be the result of recent vicariance events, probably in the Pleistocene.

Ten percent of the genera (Canephorula, Isomalopsis and Eremapis) recorded and $42.1 \%$ of the species are endemic to arid and semiarid areas of Argentina (Tab. I). According to STANGE et al. (1976), the Anthidiini in northwestern Argentina exhibits a high degree of endemism ( $60 \%$ of the species); in the case of Anthidium Fabricius, 1804, only one species is not endemic (STANGE et al. 1976). 


\section{Floral associations}

The melittophilous flora has a low diversity in the studied area, with only eight species of four families (Compositae, Zygophyllaceae, Capparaceae and Leguminosae) predominating in terms of abundance and accounting for almost the totality of the bee visits. Among these species, Cassia aphylla, with poricidal anthers, offers only pollen; the other plants offer both nectar and pollen. Some bee species had their period of activity clearly synchronized with the flowering period of Zygophyllaceae and Capparaceae species. Centris muralis, most of the Megachilidae, mainly Anthidium sp. 1, and all species of Andrenidae (Panurginae), were active only during the spring bloom of Larrea spp. and Bulnesia retama, whereas Xylocopa splendidula Lepeletier, 1841 and one species of M. (Chrysosarus) Mitchell, 1943 [M. (Chrysosarus) sp. 1] were present in both seasons, spring and late summer. Isomalopsis niveata and Svastra bombilans had their peak of activity (Fig. 4) associated with the flowering of Atamisquea emarginata (Tab. II).

The question of the floristic relationships between deserts of southwestern North America and southern South America has been largely discussed in the literature since the pioneer works by GRAY \& HOOKER (1880), ENGLER (1896) and BRAY $(1898,1900)$. Larrea and Atamisquea, both abundant elements in the Zonda region, are plants of amphitropical distribution (RAVEN 1963; SOLBRIG 1972, 1983; SIMPSON \& NEFF 1985; KIESLING 1994). In deserts of southwestern North America the vicariant species of Larrea (L. tridentata) is visited by about 90 species of bees, 22 of them oligolectic or preferential visitors (HURD \& LINSLEY 1975). Such association of specialist bees, observed by Hurd and Linsley, in the North American deserts, is very distinct, in terms of taxonomic guilds, from that verified in the Zonda Valley; there are only two genera in common: Calliopsis and Colletes. Hurd and Linsley verified also Caupolicana yarrowi (Cresson, 1875) as a regular visitor of Larrea, however in Zonda, species of this genus were never seen on Larrea, although one relatively common species, C. mystica (Schrottky, 1902), occurs there - besides the six individuals collected in this survey, another 10 were recorded in additional samplings, but none of them on Larrea flowers.

In the case of Atamisquea emarginata, on the other hand, there is no record of bee visits in North American deserts [only MolDENKE (1979a) mentions Anthophora Latreille, 1803, Centris Fabricius, 1804 and Perdita Smith, 1853 as visitor of Capparaceae], whereas in the Zonda Valley, flowers of this species were targets of $33 \%$ of the bee species collected ( $24 \%$ of the individuals).

\section{CONCLUSION}

In a general way, the bee community of the pre-Andean arid valley of Zonda is structured in two distinct seasonal cycles associated with the different plant blooming periods. Some bee species are active in the early Spring associated with the first bloom of Zygophyllaceae, among them, two reappear in the second bloom, in late Summer. The other bee species, like Canephorula apiformis and Isomalopsis niveata, are active from mid Spring to Summer, associated mainly with other plant species, but there is no species-specific associations with the flowers, as recorded for several bees in North American deserts, like many of the visitors of Larrea tridentata (HURD \& LinSLEY 1975; MOLDENKE 1976b, 1979b). 
ACKNOWLEDGEMENTS. We thank Pe. J. S. Moure and Silvia R. M. Pedro for identification of several bee species, F. Zanella for identification of $P$. (Paracentris) lyngbyei and Francisco Maldonado, Justo Marques and Mabel Allende of the Instituto y Museo de Ciencias Naturales de la Fac. de Cien. Exactas, Fisicas y Naturales de la UNSJ, for identification of the plants. We are very grateful to J.G. Rozen, Jr., R.W. Brooks, D.W. Roubik, S.R.M. Pedro, G.A.R. Melo, M.L. Oliveira for corrections, comments and suggestions. This research was supported by FAPESP (ERFM, proc. 96/3676-8) and CNPq (JMFC, proc. 300014/84-8 RN).

\section{REFERENCES}

Aparicio, E.P. 1966. Rasgos geomorfológicos de la Província de San Juan. Acta Cuyana de Ingeniería 8 (1): 81-131.

- 1984. Geología de San Juan. San Juan, Fac. de Cien. Exactas, Fisicas y Naturales. Univ. Nac. de San Juan, 167p.

BRAY, W.L. 1898. On the relation of the flora of the Lower Sonoran Zone in North America to the flora of the arid zones of Chile and Argentina. Bot. Gazette 26: 121-147.

1900. The relation of the North American flora to that of South America. Science 12: 709-716.

Cabrera, A.L. \& A. Willink. 1973. Biogeografía de América Latina. Washington, D.C., Prog. Reg. Des. Cient. y Tecnol. OEA, no. 13, 120p.

DuCKE, A. 1910. Explorações botânicas e entomológicas no Estado do Ceará. Rev. Trimest. Inst. Ceará 24: 3-61.

ENGLER, A. 1896. Über die geographische Verbreitung der Zygophyllaceen im verhältnis zu ihrer systematischen Gliderung. Phys. Abh. K. Akad. Wiss. Berlin 2: 1-36.

GrAY, A. \& J.D. HOOKLR. 1880. The vegetation of the Rocky Mountains region and a comparison with that of other parts of the world. Bull. U.S. Geol. Surv. 6: 1-77.

HuRD, P.D. \& E.G. LinsLEY. 1975. The principal Larrea bees of the southwestern United States (Hymenoptera: Apoidea). Smiths. Contrib. Zool. 193: 1-74.

Jörgensen, P. 1912. Revision der Apiden der Provinz Mendoza, Republica Argentina. Zool. Jahrb. Abt. Sys. Geogr. Biol. Tiere 32: 89-162.

Kiesling, R. 1994. Flora de San Juan, República Argentina. Ed. V. Mazzini, Buenos Aires. Vol. I, $348 \mathrm{p}$.

MiCHEnER, C.D. 1979. Biogeography of the Bees. Ann. Missouri Bot. Gard. 66: 277-347.

1989. Classification of American Colletinae (Hymenoptera, Apoidea). Univ. Kansas Sci. Bull. 53: 622-703

Michener, C.D.; W.E. Lıberge \& J.S. Moure. 1955. Canephorulini, a tribe of South American bees (Hymenopt.- Apoidea). Dusenia, Curitiba, 6 (5): 207-212.

Michener, C.D. \& J.S. MOURE. 1957. A study of the classification on the more primitive non-parasite Anthophorine bees (Hymenoptera, Apoidea). Bull. Amer. Mus. Nat. Hist. 112 (5): 395-452.

MoldenKe, A.R. 1976a. California pollination ecology and vegetation types. Phytologia 34: 305-361. . 1976b. Evolutionary history and diversity of the bee faunas of Chile and Pacific North America. Wasmann Jour. Biol. 34: 147-178.

- 1979a. Host-plant coevolution and the diversity of bees in relation to the flora of North America. Phytologia 43: 357-419.

.1979b. Pollination ecology as an assay for ecosystemic organizations: convergent evolution

in Chile and California. Phytologia 42: 415-454.

MourE, J.S. 1950. Alguns agrupamentos novos de abelhas Neotropicais (Hymenopt. - Apoidea). Dusenia, Curitiba, 1 (6): 385-394.

Raven, P.H. 1963. Amphitropical relations in the flora of North and South America. Quart. Rev. Biol. 38: $151-177$.

RolG-ALsINA, A. 1991. Revision of the cleptoparasitic bee tribe Isepeolini (Hymenoptera: 
Anthophoridae). Univ. Kansas Sci. Bull. 54: 257-288.

Silveira, F.A. 1995. Phylogenetic relationships and classification of Exomalopsini with a new tribe

Teratognathini (Hymenoptera: Apoidea). Univ. Kansas Sci. Bull. 55 (12): 425-454.

Silveira, F.A. \& J.R. CuRE. 1993. High-altitude bee fauna of southeastern Brazil: implications for biogeographic patterns (Hymenoptera: Apoidea). Stud. Neotrop. Fauna Environ. 28 (1): 47-55.

Simpson, B.B. \& J.L. NEFF. 1985. Plants, their pollinating bees, and the great American interchange, p.

427-452. In: F.G. STEHLI\& S.O. WEBB (Eds). The Great American Biotic Interchange. New York, Plenum, 532p.

SNelling, R.R. 1974. Notes on the distribution and taxonomy of some North American Centris

(Hymenoptera: Anthophoridae). Contrib. Sci. (259): 1-41.

1984. Studies on the taxonomy and distribution of American centridine bees (Hymenoptera:

Anthophoridae). Contrib. Sci. (347): 1-69.

SolBriG, O.T. 1972. New approaches to the study of disjunctions with special emphasis on the American amphitropical deserts disjunctions, p. 85-100. In: D.H. Valentine (Ed.), Taxonomy, Phytogeography and Evolution.. New York, Academic Press, XII+432p.

Solbrig, O.T. 1983. The floristic disjunctions between the Monte in Argentina and Sonoran desert in

Mexico and the United States. Ann. Missouri Bot. Gard. 59: 218-223.

Stange, L.A.; A.L. TerAn \& A. Willink. 1976. Entomofauna de la Provincia Biogeográfica del Monte.

Acta Zool. Lilloana 32: 72-120.

Recebido em 26.VIII.1999; aceito em 22.VIII.2000. 